\title{
ПРОБЛЕМЫ ИСПОЛЬЗОВАНИЯ КОНСТРУКЦИИ ДОГОВОРА ПОЖЕРТВОВАНИЯ ПРИ РЕАЛИЗАЦИИ ПРОГРАММЫ РЕНОВАЦИИ ЖИЛИЩНОГО ФОНДА В ГОРОДЕ МОСКВЕ
}

\section{PROBLEMS OF USING THE STRUCTURE OF A DONATION AGREEMENT DURING THE IMPLEMENTATION \\ OF THE RENOVATION OF HOUSING PROGRAM IN MOSCOW}

N. Ershova

Summary. Prevention of the formation of hazardous housing stock, which is one of the main goals of the Renovation of housing Program in Moscow, involves the demolition of apartment buildings included in this program, as well as the provision of equivalent apartments to owners and tenants on social rental terms. The transfer of ownership to vacated residential premises in apartment buildings subject to demolition, as well as to the provided equivalent residential premises in new buildings, is carried out through the conclusion of donation agreements between the Moscow Foundation for the Renovation of Residential Development and the Moscow City Property Department.

In this article, the author analyzed these donation agreements, and concluded that donation agreements concluded between the Moscow Foundation for the Renovation of Residential Development and the Moscow City Property Department, with the aim of demolishing residential buildings or providing equivalent apartments, the corresponding obligations to control the demolition of multi-apartment buildings. houses, as well as on issuing orders on the provision of equivalent apartments and on the actual provision of these residential premises to citizens within the framework of the Renovation Program, do not contain, in connection with which the author makes a proposal to amend donation agreements. In addition, the article concludes that it is necessary to bring the subject composition of these contracts in accordance with the provisions of Article 582 of the Civil Code of the Russian Federation.

Keywords: renovation, donation agreement, Moscow fund for the renovation of residential buildings, housing stock, donee.

\author{
Ершова Нелли Александровна \\ Аспирант, ФГБОУ ВО «Московский государственный \\ юридический университет имени О.Е. Кутафина \\ (МГЮА)» \\ ershova_nelly@mail.ru
}

Аннотация. Предотвращение образования аварийного жилищного фонда, являющееся одной из основных целей Программы реновации жилищного фонда в городе Москве, предполагает снос многоквартирных домов, включенных в данную программу, а также предоставление собственникам и нанимателям на условиях социального найма отселяемых жилых помещений равнозначных квартир. Переход права собственности на освобождаемые жилые помещения в многоквартирных домах, подлежащих сносу, а также на предоставляемые равнозначные жилые помещения в домах-новостройках осуществляется посредством заключения между Московским фондом реновации жилой застройки и Департаментом городского имущества города Москвы договоров пожертвования.

В настоящей статье автором проведен анализ данных договоров пожертвования, а сделан вывод о том, заключаемые между Московским фондом реновации жилой застройки и Департаментом городского имущества города Москвы договоры пожертвования, имея своей целью снос жилых домов либо предоставление равнозначных квартир, соответствующие обязанности по контролю за сносом многоквартирных домов, а также по изданию распоряжений о предоставлении равнозначных квартир и по реальному предоставлению данных жилых помещений гражданам в рамках Программы реновации, не содержат, в связи с чем автор выступает с предложением по внесению изменений в договоры пожертвования. Кроме того, в статье сделан вывод о необходимости приведении субъектного состава данных договоров в соответствие с положениями статьи 582 Гражданского кодекса Российской Федерации.

Ключевые слова: реновация, договор пожертвования, Московский фонд реновации жилой застройки, жилищный фонд, одаряемый.

время более 1 миллиона москвичей обретут в рамках данной программы новое благоустроенное жилище [7].

Согласно пункту 1 части 1 статьи 1 Закона города Москвы от 17.05.2017 № 14 «О дополнительных гарантиях жилищных и имущественных прав физических и юридических лиц при осуществлении реновации 
жилищного фонда в городе Москве» под реновацией жилищного фонда в городе Москве понимается совокупность мероприятий, осуществляемых в целях предотвращения формирования аварийного жилищного фонда в городе Москве, обеспечения устойчивого развития жилых территорий, создания благоприятной среды жизнедеятельности, общественных пространств и благоустройства территории и предусматривающих комплексное обновление среды проживания граждан.

Получение равнозначных квартир в районе проживания является стандартом, «общим правилом» реновации столичного жилищного фонда. Претендовать на безвозмездное предоставление равнозначных квартир могут как собственники жилых помещений (квартир либо комнат) в многоквартирных домах, включенных в программу реновации, так и наниматели, проживающие в таких же жилых помещениях (комнатах либо квартирах) на основании договора социального найма [1].

Равнозначное жилое помещение - это квартира в доме-новостройке, находящаяся в том же, что и освобождаемое жилое помещение, районе, жилая площадь и количество комнат в которой не меньше жилой площади и количества комнат в освобождаемом жилом помещении, а общая площадь превышает общую площадь освобождаемого жилого помещения, а также отвечающая стандартам благоустройства, установленным законодательством города Москвы, и имеющая улучшенную отделку в соответствии с требованиями, установленными нормативным правовым актом города Москвы [3].

Программа реновации также предусматривает новые возмездные (за доплату, в том числе со скидкой) способы улучшения жилищных условий собственников либо нанимателей по договору социального найма путем приобретения (как в момент переезда, так и в течение двух последующих лет) находящихся в собственности Московского фонда реновации жилой застройки (далее также - Московский фонд реновации, Фонд реновации) квартир большей площади, с большим количеством комнат либо дополнительных жилых помещений (общей площадью не более 100 квадратных метров) [8].

Реновация жилищного фонда представляет собой совокупность складывающихся на разных ее этапах отношений между участниками данной программы, состав которых меняется в зависимости от стадии ее реализации, однако почти на всех этапах реновации одну из ключевых ролей в претворении указанной программы в жизнь играет Московский фонд реновации жилой застройки.
Фонд реновации представляет собой унитарную некоммерческую организацию, учреждаемую Правительством Москвы в лице Департамента строительства города Москвы в организационно-правовой форме фонда в целях содействия обновлению среды жизнедеятельности и созданию благоприятных условий проживания граждан, общественного пространства для предотвращения роста аварийного жилищного фонда в городе Москве, обеспечения развития жилых территорий и их благоустройства. Деятельность Московского фонда реновации регламентируется постановлением Правительства Москвы от 08.08.2017 № 517-ПП «Об учреждении Московского фонда реновации жилой застройки», а также Уставом Фонда, утвержденным решением Совета Московского фонда реновации жилой застройки (протокол от 13.11.2018).

Московский фонд реновации жилой застройки, в частности, наделен функциями по оказанию содействия при осуществлении сноса многоквартирных домов, включенных в решения о реновации, передаче городу Москве, уполномоченному органу исполнительной власти города Москвы жилых помещений, принадлежащих фонду на праве собственности, в том числе по безвозмездной передаче таких жилых помещений в виде пожертвования (пункты 2.2.2., 2.2.9. Устава Фонда) [6]. Таким уполномоченным органом исполнительной власти города Москвы является Департамент городского имущества города Москвы.

В силу пункта 1 статьи 582 Гражданского кодекса Российской Федерации пожертвованием признается дарение вещи или права в общеполезных целях. Согласно указанному пункту субъектный состав одаряемых по договору пожертвования является закрытым: пожертвование вправе получить граждане, медицинские, образовательные организации, организации социального обслуживания и другие аналогичные организации, благотворительные и научные организации, фонды, музеи и другие учреждения культуры, общественные и религиозные организации, иные некоммерческие организации в соответствии с законом, а также Российская Федерация, субъекты РФ и муниципальные образования [2].

Анализ приведенной нормы свидетельствует о том, что передать вещь по договору пожертвования публично-правовому образованию (Российской Федерации, субъекту Российской Федерации и муниципальному образованию) возможно, тогда как пожертвование в пользу органов исполнительной власти законом не предусмотрено.

Принимая во внимание изложенное, было бы более верным указывать в договорах пожертвования в каче- 
стве одаряемого не сам Департамент городского имущества города Москвы, а субъект Российской Федерации - город Москву в лице Департамента городского имущества города Москвы как уполномоченного органа исполнительной власти города Москвы.

В настоящее время Московский фонд реновации жилой застройки и Департамент городского имущества города Москвы заключают два вида договоров пожертвования: о передаче принадлежащих Фонду реновации жилых помещений для последующего сноса жилых домов, в которых располагаются данные объекты недвижимости, а также о передаче находящихся в собственности Московского фонда реновации жилых помещений в домах-новостройках для последующего предоставления данных квартир гражданам в качестве равнозначных жилых помещений в рамках Программы реновации.

Думается, что данная договорная конструкция была избрана для того, чтобы обеспечить Фонду реновации право и возможность контролировать использование имущества, передаваемого в качестве пожертвования, на предмет соответствия цели, установленной в договоре (цель - снос многоквартирного дома, включенного в программу реновации, либо предоставление гражданам равнозначных жилых помещений), а также для того, чтобы исключить поступившие в собственность города Москвы жилые помещения из налогооблагаемой базы.

Предметом договоров пожертвования, заключаемых между Московским фондом реновации жилой застройки и Департаментом городского имущества города Москвы, является безвозмездная передача жертвователем (Фондом реновации) одаряемому (Департаменту городского имущества города Москвы) объектов недвижимого имущества - жилых помещений (квартир), принадлежащих жертвователю на праве собственности. Целью поступления данных объектов недвижимого имущества в собственность города Москвы является последующая ликвидация жилого дома и дальнейшее использование земельного участка при реализации программы реновации жилищного фонда в городе Москве в соответствии с Постановлением Правительства Москвы от 01.08.2017 № 497-ПП «О Программе реновации жилищного фонда в городе Москве (при заключения договоров пожертвования для сноса жилых домов) [5] либо последующее предоставление собственникам и нанимателям по договору социального найма передаваемых Московским фондом реновации квартир в качестве равнозначных жилых помещений (при заключении договоров пожертвования в отношении домов-новостроек).
Согласно заключаемым в рамках Программы реновации договорам пожертвования жертвователь принимает на себя обязательства по передаче указанных в договоре жилых помещений (конкретизированных в приложении к договору и акте приема-передачи), а также по предоставлению совместно с одаряемым пакета документов в Управление Федеральной службы регистрации, кадастра и картографии по Москве для государственной регистрации перехода права собственности на передаваемое имущество. Одаряемый в соответствии с такими договорами пожертвования обязуется принять у жертвователя передаваемое имущество, а также предоставить совместно с жертвователем пакет документов в Управление Федеральной службы регистрации, кадастра и картографии по Москве для государственной регистрации перехода права собственности на передаваемое имущество. В договорах пожертвования также указывается на то, что передача имущества осуществляется одновременно с подписанием данного договора.

Таким образом, анализ данных договоров пожертвования позволяет сделать вывод о том, что в настоящее время такие договоры пожертвования, имея своей целью последующую ликвидацию жилых домов либо предоставление равнозначных жилых помещений, вместе с тем не содержат обязанность Департамента городского имущества города Москвы по осуществлению контроля за сносом перешедших в собственность города Москвы жилых домов, а также обязанность предоставить квартиры в домах-новостройках гражданам в качестве равнозначных жилых помещений. Отсутствует соответствующая обязанность и в Положении о Департаменте городского имущества города Москвы, утвержденном постановлением Правительства Москвы от 20.02.2013 № 99-ПП [4].

По мнению автора, для обеспечения Департаментом городского имущества города Москвы реализации указанной в договорах пожертвования цели (последующий снос жилого дома либо последующее предоставление равнозначных квартир) и предупреждения ситуации нецелевого использования многоквартирных домов, подлежащих сносу (в том числе посредством предоставления жилых помещений на основании заключаемых с городом Москвой договоров) и, напротив, подлежащих заселению, представляется целесообразным дополнить обязательства одаряемого (Департамента городского имущества города Москвы) в рамках договоров пожертвования, указав на его обязанность по контролю за сносом включенных в программу реновации жилых домов, а также на обязанность издать распоряжение о предоставлении собственникам либо нанимателям по договору социального найма равнозначных квартир в рамках Программы реновации жилищного фонда. 
ЛИТЕРАТУРА

1. Закон РФ от 15.04.1993 № 4802-1 (ред. от 01.07.2021) «0 статусе столицы Российской Федерации» // «Ведомости СНД РФ и ВС РФ», 13.05.1993, № 19, ст. 683;

2. Гражданский кодекс Российской Федерации (часть вторая) от 26.01.1996 № 14-Ф3 (ред. от 01.07.2021, с изм. от 08.07.2021) // «Собрание законодательства РФ», 29.01.1996, № 5, ст. 410;

3. Закон города Москвы от 17.05.2017 № 14 «0 дополнительных гарантиях жилищных и имущественных прав физических и юридических лиц при осуществлении реновации жилищного фонда в городе Москве» // «Вестник Мэра и Правительства Москвы», № 28, том 2, 23.05.2017;

4. Постановление Правительства Москвы от 20.02.2013 № 99-ПП «0б утверждении Положения о Департаменте городского имущества города Москвы» (ред. 28.09.2021) // «Вестник Мэра и Правительства Москвы», № 11, 26.02.2013;

5. Постановление Правительства Москвы от 01.08.2017 № 497-ПП «0 Программе реновации жилищного фонда в городе Москве» (ред. 0т 21.09.2021) // СПС «КонсультантПлюс»;

6. Устав Московского фонда реновации жилой застройки, утвержденный распоряжением Департамента строительства города Москвы от 22.09 .2017 № P-93/17 // [Электронный ресурс] официальный сайт Московского фонда реновации жилой застройки // URL: https://fr.mos.ru/0-fonde/dokumentyfonda/ (дата обращения - 01.09.2021);

7. Статья «Число расселяемых домов со старта программы реновации достигло 148» // [Электронный ресурс] официальный сайт Комплекса градостроительной политики и строительства города Москвы // URL: https://stroi.mos.ru/news/chislo-rassieliaiemykh-domov-so-starta-proghrammy-rienovatsiidostighlo-148 //(дата обращения — 01.09.2021);

8. Статья «Покупка недвижимости» // [Электронный ресурс] официальный сайт Московского фонда реновации жилой застройки // URL: https://fr.mos.ru/ pokupka-nedvizhimosti/ (дата обращения — 01.09.2021).

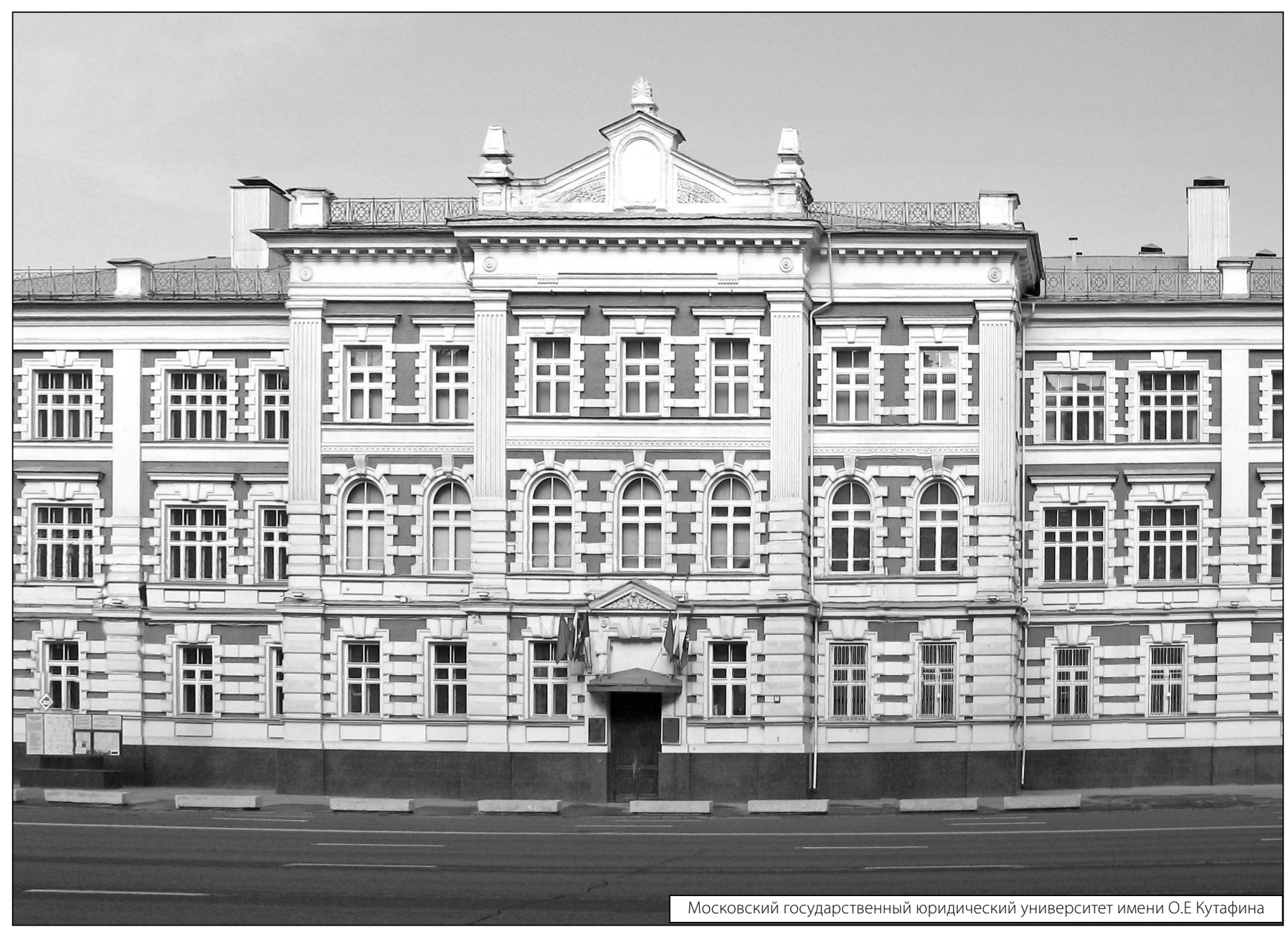

